\title{
The impact of Acremonium endophytes in New Zealand, past, present and future
}

\section{L.R. FLETCHER, J.H. HOGLLJND and B.L. SUTHERLAND} DSIR Grasslands, Private Bag, Christchurch

\begin{abstract}
This paper reviews some of the current practical and economic implications of Acremonium endophytes of ryegrass and tall fescue in New Zealand grassland agriculture. A historical perspective of their discovery and possible future implications of a new "novel" endophyte strain are also covered.
\end{abstract}

K eywords Acremonium, endophyte, ryegrass, Lolium, tall fescue, staggers, Argentine stem weevil, clover, liveweight gains

\section{Introduction}

Establishment of the link between an endophyte (Acremonium Iolii Latch, Christensen and Samuels) of perennial ryegrass (Lolium perenne L.) and ryegrass staggers (Fletcher \& Harvey 1981) and then subsequently a further link with Argentine stem weevil (Listronotus bonariensis Kuschel) (Prestidge et al. 1982; Mortimer et al. 1982) has resulted in ryegrass and endophyte being regarded as synonomous by farmers and seed merchants alike. Despite this rise in awareness, endophytes in grasses are not new,_and they_are_not restricted to ryegrass The term endophyte (Greek: endo = within + phyte $=$ plant) has been defined as an organism contained or growing (entirely) within the substrate of a plant whether parasitic or not (Walker 1950; Snell \& Dick 1971). For the purpose of this paper, endophytes are fungi living entirely within a plant in the intercellular spaces of the host tissue. Endophytic fungi within seeds and plants of pasture grasses have been recognised since last century, but endophytes of perennial ryegrass and tall fescue (Festuca arundinacae Schreb.) have been studied more specifically throughout the-first half of this century (Vogl 1898; McLennan 1920; Sampson 1933, 1935, 1937; Neill 1940, 1941, Lloyd 1959).

A. Iolii, formerly referred to broadly as Lolium endophyte, and presumed to be "Neills lolium endophyte No. 1", is found' in perennial ryegrass, while Acremonium coenophiulum Morgan-Jones and Gams, is found in tall fescue (Latch et al. 1984).

Both these Acremonium endophytes in conjunction with their hosts are now recognised as having a major impact in grasslands agriculture both in New Zealand and overseas. They are strikingly similar both morphologically and serologically (Siegel et al. 1985). They are both concentrated in the leaf sheath and flowering stem of the plant with little or no mycelia in the leaf or roots, and they have no visible effect on the plant, having no external phase and producing no fruiting bodies in their host. Their relationship with their host is regarded as mutualistic (Siegel et al. 1985).

Tall fescue and perennial ryegrass, and presumably their endophytes, originated in Europe and were imported into New Zealand last century (Siegel et al. 1985). Despite being regarded as inconsequential for three-quarters of a century, A. Iolii has recently been raised in our consciousness. Awareness has increased over the last decade as it has been linked with other positive and negative effects. Many of these effects would have been recognised since perennial ryegrass was first introduced into New Zealand, but were not linked with endophyte. Since it has no visible effect on the host plant, this was not surprising.

A. coenophialum in tall fescue has had a small impact on grasslands agriculture in New Zealand, although to a much lesser extent than A. Iolii in ryegrass. Tall fescue has never been as popular as ryegrass for pastures, particularly since tall fescue per se was linked with the fescue foot syndrome (Cunningham 1948). Interest in tall fescue, as an alternative perennial forage grass to ryegrass, is again increasing as both the New Zealand bred and currently imported cultivars do not have an endophyte, and are non toxic (Belgrave et al. 1990).

Although the Acremonium endophytes of tall fescue and ryegrass are very similar, the associated syndromes in grazing animals are quite different. A. lolii in ryegrass produces a neuromuscular syndrome: ryegrass staggers (Keogh 1973; Mortimer 1983); A. coenophialum in tall fescue produces a thermoregulatory syndrome: fescue toxicoses (Bacon et al. 1977; Hoveland et al. 1983). Fescue foot has also been ascribed to the $A$. coenophiulum tall fescue relationship (Garner \& Cornell 1978; Hemken et al. 1984). Both these disorders have been recorded in New Zealand in the past in animals grazing "wild" tall fescue containing A. coenophiulum (Kearns 1985). These disorders are no longer a threat with new sowings of the currently available non- 
endophyte forage tall fescues, although grazing of wild fescue can still cause problems. Turf tall fescues with high levels of $\mathbf{A}$. coenophialium, introduced for seed multiplication, have also caused fescue foot in sheep and cattle.

Despite the increasing awareness and use of alternatives, such as tall fescue, perennial ryegrass still forms the basis $(80 \%)$ of our arable pastures. Thus the Acremonium endophytes have the potential to affect a large proportion of these pastures, especially in drier regions where endophyte effects are most pronounced. The significance of these drier regions could increase with predicted climatic change.

This paper reviews some of the current practical and economic implications of these endophytes in New Zealand grasslands agriculture, looks at their historical effects, and predicts their possible future role.

\section{Ryegrass staggers}

Ryegrass staggers is a neuromuscular disorder of sheep, cattle, horses, deer, and occasionally goats, grazing perennial ryegrass containing $\mathbf{A}$. Iolii, usually during summer and autumn (Keogh 1973; Mortimer 1983). Typical conditions which predispose the development of ryegrass staggers are close grazing ryegrass-dominant pastures during or subsequent to prolonged warm dry conditions. Such pastures often have high basal dead matter content (Keogh 1973; Latch et al. 1976). However, ryegrass staggers does occur outside these bounds, with an increase in reports of the disorder in animals grazing green grass, including dairy cattle.

Ryegrass staggers should not be confused with "grass staggers", which has some symptoms in common, but is the result of hypomagnesaemia occurring in sheep and cattle on rapidly growing pasture in spring (Mortimer 1983).

Some species and breeds of animals are more susceptible to ryegrass staggers than others, e.g. deer are very susceptible and take longer to recover. There is also a wide range of susceptibility within a group of animals on the same pasture, often ranging from those showing no obvious clinical symptoms to those unable to stand.

When undisturbed most affected animals show little abnormality; however once disturbed, or made to run, clinical symptoms rapidly become apparent. The mildest symptoms are a slight trembling of the head, face, neck, shoulder and flank regions (Keogh 1973). The disorder progresses through head nodding, jerky limb movements, swaying while standing and staggering during movement. As the condition worsens, a stiff leg gait develops, usually resulting in animals falling over with head extended, arched back and rigid limbs (Mortimer 1983). When left alone the animal will regain its feet and walk off. In seriously affected animals these symptoms are condensed, with head nodding and body swaying even when unstimulated. Such animals often fall over as soon as disturbed. The worst affected animals may become permanently recumbent and eventually die as a primary result of the disorder.

Moderate outbreaks are often regarded as a nuisance, with deaths resulting only from misadventure, secondary to the disorder; However, in severe outbreaks, deaths can occur as a primary result of ryegrass staggers. Deaths are tangible and costly, as are some control measures, such as hay feeding (Everest 1983). At the very least, ryegrass staggers creates major management problems when animals are required to be yarded or trucked for normally routine operations. Costs and losses due to delays in dipping, lamb drafting and drenching are just as significant but less obvious.

Ryegrass staggers has most likely been occurring in New Zealand since the introduction of ryegrass, and presumably A. lolii, from Europe last century, but it was first described and documented at the beginning of this century (Gilruth 1906). Little serious research was carried out on the problem until the late 1950s. The search for the causal agent of the disorder continued over the next 20 years with evidence for such suspected agents as ergot (Thornton 1964), alkaloids (Aasen et al. 1969), saprophytic fungi (Latch et al. 1976) and soil fungi (di Menna et al. 1976). Conditions predisposing the disorder were also thoroughly researched (Keogh 1973, 1978). A. Iolii, which is concentrated in the leaf sheath of the ryegrass plant, was eventually discovered to be the causal agent (Fletcher \& Harvey 1981).

The toxin believed responsible for ryegrass staggers, lolitrem B, was discovered about the same time, although it was not linked with the presence of A. lolii in the ryegrass at that time (Gallagher et al. 1981). To date the toxin has not been produced by A. lolii in culture; it can be extracted only from ryegrass containing A. lolii. It is therefore unclear whether lolitrem B is of fungal or plant origin (Weedon \& Mantle 1987). The structure of lolitrem B has been established and the toxin tested in mice for ryegrass staggers symptoms (Gallagher et al. 1984; Gallagher \& Hawkes 1985, 1986).

Long before it was established that $\mathbf{A}$. Iolii and lolitrem B were concentrated in the basal leaf sheath material of ryegrass (Musgrave \& Fletcher 1984; Prestidge \& Gallagher 1985), the toxic agent was identified as being associated with the basal portion of ryegrass pastures, as close grazing increased the incidence and severity of ryegrass staggers (Keogh 1973). Increasing the amount of dead ryegrass material under natural environmental conditions or artificially by spraying with herbicides, also increased the incidence and severity of staggers (Fletcher \& Piper 1990). Surface soil temperatures appear to have an overriding influence on the development of the disorder.

Although A. Iolii is essential to the toxic relationship, grazing ryegrass containing $\mathbf{A}$. Io/ii does 
not universally result in the development of ryegrass staggers. Neither does the concentration of $A$. lolii in plant tissue necessarily relate to the incidence or severity of ryegrass staggers in the grazing animal. The disorder rarely occurs on fully irrigated unstressed pastures, which characteristically have low dead matter content, despite high levels of endophyte and close grazing. Ryegrass staggers never occurs in the winter, again despite high dead matter content and extreme close grazing of high endophyte ryegrass. Toxin levels appear to increase greatly during natural or artificially induced (herbicide treatment) senescence which is consistent with dead tissue being more toxic than unstressed actively growing tissue (Fletcher \& Piper 1990).

Compounding and interacting effects of drought, including summer feed shortage and intensive hard grazing of ryegrass pastures, are often unavoidable if stock numbers are to be maintained. Avoiding set stocking, close grazing and build-up of dead material in pastures, moving animals to non-ryegrass or nontoxic pastures and feeding hay are short term options which may help alleviate ryegrass staggers if the farm system is flexible enough to allow them (Keogh 1983). Establishment of non-endophyte pastures would be the obvious long term option of prevention of ryegrass staggers. However, non-endophyte ryegrass pastures may not survive in the face of Argentine stem weevil attack, especially in the drier regions where ryegrass staggers and Argentine stem weevil damage are greatest. Other options for prevention or control are often limited in these dry regions, but may include the establishment of alternative pasture species.

\section{Argentine stem weevil}

Argentine stem weevil-is-one.of-New-Zealand's-major pasture insect pests and its damage in pastoral and arable agriculture is well known (Kelsey 1958; Pottinger 1961; Goldson \& Trought 1980). The weevil was first recorded as a minor pest of cereals. It was first identified as a major pasture pest with the introduction of the highly susceptible 'Grasslands Manawa' ryegrass in the 1940 s. Estimated production losses are \$120-150 million annually (Prestidge et al. 1985).

Argentine stem weevil completes two generations a year in most parts of New Zealand, but three generations may occur in the warmer moist northern districts. For the spring generation eggs appear in August-September and adults in December. The second generation starts developing in January reaching adult by March-April. The adults overwinter and the cycle begins again in spring. In Canterbury and other drier regions, the spring generation is the largest and generally causes the most damage. Dispersal flights occur during spring to late autumn on calm warm days (Prestidge et al. 1985).
Damage can occur in pastures of any age. In dry summers, which are frequent in Canterbury, pastures less than a year old can be eliminated. Adult feeding leaves window like scars in grass leaves; this damage is generally only important in young pastures established in summer. The larval stage is the most damaging with 1 larva capable of killing 3-5 tillers plus new replacement tillers. Damage is naturally greater during drought as the grasses' ability to generate new tillers is restricted. Conversely damage in warm moist summer conditions is much less noticeable owing to continued replacement of damaged tillers with new ones (Prestidge et al. 1985).

Ryegrasses naturally resistant to stem weevil attack had been identified in the laboratory and in the field but the reason for the resistance was unexplained at the time. Lower numbers of eggs and larvae were found in Takapau and Ellett ryegrass than in 'Grasslands Ruanui' and 'Grasslands Nui' (Goldson 1979; Kain et al. 1982).

Plots of perennial ryegrass with and without endophyte, established to confirm $A$. lolii as the cause of ryegrass staggers, showed marked differences in recovery after summer grazing (Mortimer et al. 1982; Prestidge et al. 1982). It was discovered that $A$. lolii was protecting perennial ryegrass from Argentine stem weevil attack and damage. This disclosure, coupled with the association of $A$. lolii with ryegrass staggers, posed an immediate dilemma. The establishment of endophyte-free pastures was no longer a simple option to avoid ryegrass staggers, since $A$. lolii was also giving economic and environmentally safe protection against a major ryegrass pest, In retrospect, the ryegrasses previously described as naturally resistant (Takapau and Ellett) contained $A$. lolii while those attacked (Ruanui and Nui) had lower and variable levels; Altho $\overline{\text { ugh }}{ }^{-}$the toxin causing ryegrass staggers, lolitrem $\mathrm{B}$, is toxic to Argentine stem weevil larvae, the major adult feeding deterrent has been extracted and identified as perarnine (Prestidge \& Gallagher 1985; Rowan \& Gaynor 1986). Peramine is water soluble, lolitrem B is lipid soluble. Unlike lolitrem B, peramine is produced by A. lolii in culture.

Argentine stem weevil can be controlled to some extent by spraying with the insecticides oxymel or chloropyrifos, and although these can increase pasture production, control is incomplete and expensive (Prestidge et al. 1985). Spraying is also less attractive in today's environmentally conscious society. With increasing use of biological control methods, as opposed to pesticides, and the need to develop low input sustainable agricultural systems, A. lolii is an attractive means of control of Argentine stem weevil damage in ryegrass (Goldson et al. 1990). However, this is dependent on its link with ryegrass staggers being reduced or eliminated.

Other methods of biologically controlling Argentine stem weevil are being considered. A 
parasitoid that lives on Argentine stem weevil has recently been brought into New Zealand and is now being evaluated in quarantine. It is not expected to eradicate Argentine stem weevil but should have a complementary effect with $\mathbf{A}$. Iolii in controlling the effects of Argentine stem weevil (Goldson et al. 1990).

\section{Clover production}

Clover, and particularly white clover (Trifolium repens L.), has always been an important component of developed pastures in New Zealand. Nitrogen fixation and high pasture quality for animals are both important functions of the clover content in pastures (Suckling 1965). However, clover contribution in many developed pastures, especially those with ryegrass, has often been low (Suckling 1975), even when conditions for optimal clover growth in ryegrass-white clover pastures were identified and applied. The problem was regarded as associated with older, persistent, poor quality, ryegrass pastures and was often blamed on overgrazing and "run out" of pastures. Some ryegrass cultivars appeared to be more compatible with clover than others (Harris \& Hoglund 1977).

Farmers also suggested that clover played a role in prevention of ryegrass staggers, since ryegrass pastures with low clover content appeared to be the most toxic in terms of ryegrass staggers. In retrospect, old pastures that had survived natural selection, pastures that caused ryegrass staggers and the variable effect of different cultivars on clover production, were all related to the presence of $\mathbf{A}$. lolii. Under grazing, it is interesting to note that in spring, sheep prefer non-endophyte ryegrass to white clover, with ryegrass containing $\mathbf{A}$. lolii being the least preferred. The preference could give clover a further competitive advantage in non-endophyte pastures under grazing ( $H$. Eerens pers. comm.).

It has recently been reported that ryegrass containing A. lolii suppressed white clover relative to comparable endophyte-free ryegrass (Sutherland \& Hoglund 1989). This reduction in clover contribution was a function of both lower plant survival and reduced vigour of the surviving plants. Approximately $50 \%$ of the reduction in clover production could be accounted for by increased direct competition from the move vigorous endophyte ryegrass. However, unexplained residual variation was consistent with an allelopathic effect of A. Iolii. This suspicion of an allelopathic effect was supported in a subsequent trial when endophyte ryegrass reduced clover growth, even when grass yields were below those of endophyte-free lines of the same cultivar (Stevens \& Hickey 1990). These adverse effects of A. Iolii on the clover component appear less pronounced in high rainfall areas or under irrigation

Reducing the rate of ryegrass in ryegrass-white clover seed mixtures has been suggested as a simple solution to the problem of over-dominant grasses (Sears \& Brougham 1963), at least during the establishment phase. Several seeding rates of one cultivar with A. Iolii are currently being assessed for their effect on clover contribution in ryegrass-white clover pastures at Lincoln.

Reduced nitrogen fixation in ryegrass pastures containing A. Iolii, consequent on lower clover yields, has been the presumed cause of a decline in ryegrass vigour after 3-4 years. A recovery in clover production appears to follow this change, but clover yields are not expected to equal those of clover in non-endophytic pastures.

The recent increase in popularity and use of high endophyte ryegrass cultivars will increase problems of low legume contribution in ryegrass-white clover pastures. The effect of the new 'novel' strain of endophyte on clover production has yet to be evaluated.

\section{Other effects}

Although the effect of $\mathbf{A}$. Iolii on ryegrass staggers and Argentine stem weevil has received the greatest attention, this endophyte can have other significant, but less obvious effects. Ryegrass plants containing A. Iolii have grown up to $50 \%$ more herbage than those without $\mathbf{A}$. Iolii in the absence of external stresses such as drought and Argentine stem weevil (Latch et al. 1985; Arechavaleta et al. 1989). The mechanism of this effect is unknown. In tall fescue, A. coenophialum has been shown to increase the nitrogen efficiency of its host (Belesky $\boldsymbol{e t}$ al. 1984; Lyons et al. 1990).

Sheep grazing ryegrass with $\mathbf{A}$. Iolii often have lower liveweight gains than sheep on similar endophyte-free ryegrass even in the absence of clinical ryegrass staggers (Fletcher 1982, 1983, 1985). The difference in liveweight gains varies, is obviously affected by environment, time of year and animal condition, and it is often greater in late spring (Fletcher 1985). Under hard grazing, liveweight gains of lambs grazing non-endophyte ryegrass have been over $100 \%$ greater than on endophyte ryegrass (Fletcher \& Piper 1985). Long term measurements have often been prematurely terminated because of ryegrass staggers or the loss of endophyte-free ryegrass to Argentine stem weevil attack in summer. The effect of A. Iolii on liveweight gains is exaggerated in animals grazing mixed ryegrass-white clover pastures, as white clover is of higher quality than ryegrass and there is usually a much higher percentage of clover when grown with nonendophyte ryegrass.

Typically, sheep grazing endophyte ryegrass have more scouring and dags than those grazing nonendophyte ryegrass. The reason for increased dags is unclear, but up to eight times more dags have been measured on sheep grazing endophyte ryegrass $(H$. Eerens unpubl. and L. Fletcher unpubl.). Observations also suggest there may also be a greater 
incidence of flystrike, independent of dags, in high endophyte ryegrass (Fletcher \& Sutherland unpubl.). At a subclinical level, sheep grazing ryegrass containing A. lolii have lower serum prolactin levels than those on ryegrass without A. lolii (Fletcher \& Barrell 1984). There is a similar reduction in prolactin in cattle grazing tall fescue with A. coenophialum (Wallner et al. 1983). The role of prolactin in the different animal species, including sheep, is not yet fully understood. Prolactin levels can be restored by administering metoclopramide to sheep and cattle (Lipham et al. 1988; Piper \& Fletcher 1990). Metoclopramide, however, did not alleviate ryegrass staggers symptoms, suggesting the dopaminergic neurons and dopamine agonists are not involved in the staggers syndrome. This suggests that the toxin responsible for lowering prolactin levels is unlikely to be lolitrem B or any toxin involved in ryegrass staggers. Although autopsies of animals with severe ryegrass staggers have not revealed any lesions, profiles of liver enzymes indicate that sheep grazing ryegrass with A. lolii can suffer impaired liver function (Piper 1989).

\section{Tall fescue and Acremonuim coenophialum}

The endophyte $A$. coenophialum in tall fescue has a major effect on the beef industry in the United States but has had little effect in New Zealand because all New Zealand bred and imported forage tall fescue cultivars are free of the endophyte. A. coenophialum in tall fescue was first linked with fescue toxicosis or "summer syndrome" of cattle in 1977 (Bacon et al. 1977). It has also been linked with fescue foot in cattle (Garner \& Cornell 1978). "Summer syndrome" occurs during hot summer-autumn conditions and may include any or all of the following- symptoms: rough- -hair coat;- rapid breathing, excessive salivation, nervousness, elevated body temperatures and increased sensitivity to heat Animals continually seek to stand in shade and wate (Hoveland et al. 1983; Mueller 1985). There are, of course, associated poor weight gains and reduced milk production in affected animals. This syndrome has been reported in Northland dairy herds grazing wild tall fescue, which normally contains $A$. coenophialum. The syndrome was referred to as idiopathic bovine hypothermia (I.B.H.) (Kearns 1985). Fescue foot is a gangrenous condition which develops in the-extremities in cattle and ultimately may result in sloughing of hooves and tips of ears and tail (Garner \& Cornell 1978; Hemken et a/. 1984). This syndrome usually occurs in winter, and usually begins with animals showing arched backs, rough coat and sore hooves. As lameness develops, swelling of the coronary band becomes evident and in severe cases the hooves (usually the rear hoof) may slough off.

A. coenophialum also causes agalactia, prolonged gestation and abortion in mares (Garret et a/. 1980).
The formation of necrotic fat or hard fat in the abdominal cavity of grazing animals and reproductive problems have also been associated with A. coenophialum (Rumsey et al. 1979).

Several alkaloids in tall fescue have been implicated in fescue toxicosis. The alkaloids $\mathrm{N}$-acetyl loline and N-formyl loline occur in tall fescue with $A$. coenophialum, but not in endophyte-free tall fescue (Bush et al. 1982; Jones et al. 1983). Although not proven that these alkaloids play a role in fescue toxicosis, they are known to be insect feeding deterrents (Johnson et al. 1985). Clavine and ergopeptide type alkaloids can be produced in vitro by $A$. coenophialum and have been measured in endophyte-infected tall fescue in the field (Bacon et al. 1986; Lyons et al. 1986; Yates et al. 1985). Ergovaline, an ergopeptide alkaloid, has received the most attention in relation to its possible involvement in fescue toxicosis (Bacon et al. 1986; Lyons et al. 1986). Many symptoms of fescue toxicosis are consistent with signs of ergot poisoning (Bacon et al. 1986).

Although the fescue toxicosis syndromes have not been common in New Zealand, there is always potential for them to occur in animals grazing "wild" tall fescue which is still common in some pastures and waste areas. The recent introduction of turf tall fescues, for seed multiplication, has also recently resulted in toxicoses problems. Some of these turf tall fescues have high levels of $A$. coenophialum. Although grown primarily for seed production, grazing herbage accumulated in early spring or post harvest or feeding straw residues from crops has potential to cause fescue toxicoses. The threat may be greater in warmer regions or in areas affected by climate warming. Grazing these areas for prolonged periods or hard grazing is not recommended, and feeding straw residues should be a supplement to adequate quantities of alternative feed. The level of A. coenophialum in crop will, of course, have the greatest bearing on the potential toxicity of the herbage.

\section{Endophyte detection, control and dissemination}

Acremonium endophytes die out in seed at a much faster rate than the natural decline in seed germination during storage under ambient conditions. Relative rates of decline in endophyte and seed viability depend on storage time, temperature, relative humidity and seed moisture content (Hare et al. 1990).

The endophyte hyphae are concentrated in the leaf sheath of the vegetative plant (Musgrave 1984; Siegel et al. 1984). As the plant enters the reproductive phase the endophyte in the vegetative apex enters the developing inflorescence primordium and flora apices from where it penetrates the tissues of ovary and ovule (Philipson \& Christey 1986). Entry into the 
embryo probably occurs soon after fertilisation. The endophyte hyphae are widespread in the embryo of the mature seed including between the cells of the aleurone layer. At germination, hyphae outside the embryo appear to play no further part in invasion of the already infected embryo. In the natural state the seed would return to the ground, germinate and give rise to a new plant containing endophyte. If this

"natural" cycle is broken and there is a prolonged delay from seed maturation to germination, as is the case with stored seed, the endophyte will eventually die, giving rise to an endophyte-free plant. Since the endophytes are transmitted only via the seed, this is the only point where the cycle can be broken "naturally", as the endophyte does not die out in live plants nor do endophyte-free plants become "naturally infected" in the field (Siegel et al. 1985).

Acremonium endophytes can be detected by several methods, the suitability of each depending on the information required. The simplest, commonest and least expensive is the examination of ryegrass leaf sheath or seeds under the light microscope (Latch \& Christenson 1985; Welty et al. 1986). Although this method gives the proportion of seeds or plants containing endophyte in a population, it does not distinguish between live and dead endophyte in seeds.

The enzyme linked immunosorbent assay (ELISA) is the only quantitative method for detecting endophyte (Johnson et al. 1982; Musgrave 1984), but the method is slow and expensive, especially for small numbers of samples. Like the previous method, it also fails to distinguish between live and dead endophyte. To ensure that live endophyte is being detected in seed when using the above two methods, seeds must first be germinated, grown on as seedlings, and the endophyte then assayed from live plant material (Latch et al. 1985).

Another very slow and laborious method of determing viable. endophyte levels is to grow the endophyte out into the culture medium (Latch \& Christensen 1985). This is often referred to as the "grow-out technique", but is rarely used for simple endophyte tests.

Killing the endophyte in plants or seeds is difficult and not without side effects (Latch \& Christensen 1982; Harvey et al. 1982; Latch et al. 1985). Some chemicals such as the benzimidazoles and ergosterol biosynthesis inhibitors, when used as high rates, will often kill the fungus in plants and seeds, but also commonly reduces seed viability and plant growth. No fungicide has proved completely reliable for this purpose. Short term heat treatment with high humidity or steam will kill the endophytes in seed but with a commensurate decrease in seed germination (Siegel et al. 1984).

Eradication of endophytes by these methods at the farming level is usually unnecessary and at best unreliable. The most desirable means of obtaining endophytl-free plants is to produce endophyte Free parent plants or cultivars. All future seed from these plants will be endophyte free.

The maintenance of high endophyte levels in seed is of much greater importance and poses major problems with large bulks of stored seed (Rolston et al. 1986). Unless seed is sown in the autumn after harvest, endophyte levels will decline under "normal" storage. Viable endophyte levels can be maintained for up to 4 years in seed at ambient temperatures if seed moisture is held below $12 \%$. Above this, levels will decline rapidly over 12 months (Hare et al. 1990). For storage periods longer than 5 years, seed will need to be stored under refrigeration $5{ }^{\circ} \mathrm{C}$ at $60-70 \%$ relative humidity in heat sealed bags which maintain seed moisture below $12 \%$.

In the past, mis-matches of supply and demand for seed of certain ryegrass cultivars have resulted in storage of large bulks of seed for future demand and led to dramatic effects on cultivar performance. Ariki ryegrass orginally had high levels of endophyte, but prolonged storage at ambient temperatures (normal storage) resulted in seed released for increases of Ariki in late 1960s and 1970s having no viable endophyte (Latch 1983). Consequently, Ariki performed variably under attack by Argentine stem weevil, for example, and as a result its popularity declined and use still remains low with the exception of Southland where Argentine stem weevil is not known to be a problem (Belgrave et al. 1990). The endophyte levels have been restored in a selection from Ariki with a low leaf strength, 'Grasslands Marsden'. Nui suffered a similar fate to that of Ariki in the $1980 \mathrm{~s}$, although to a lesser extent. Endophyte levels in ryegrass cultivars such as Ellett were maintained because of rapid turnover of seed supplies.

It is essential to know the viable endophyte level of any perennial ryegrass seedline before sowing if persistence is to be expected. If large bulks of ryegrass seed are to be stored and viable endophyte levels maintained, then specialised storage facilities with controlled temperature and humidity will need to be developed.

\section{Future}

A. lolii has passed through several phases of importance since its discovery as a lolium endophyte earlier this century. For many years it was considered inconsequential, until it was linked with ryegrass staggers, at which point it became an unwanted or negative aspect in the grasslands scene. Perception of its role rapidly changed to one of ambivalence with the establishment of its positive role in ryegrass resistance to Argentine stem weevil. This dilemma of ryegrass staggers or pasture damage by Argentine stem weevil continues, but the attitude toward $A$. lolii, as an economic and environmentally acceptable means of protecting against Argentine stem weevil attack, has become more positive, especially in the drier regions of New Zealand. Endophyte research is 
now entering a distinctly positive phase. Now that the major effects of endophyte have been established and quantified, the benefits of the endophytes are being exploited while the detrimental effects are being reduced.

After a programme of searching and screening a range of ryegrasses from various locations, a 'novel' strain of endophyte, which does not produce lolitrem $\mathrm{B}$, but protects its host from Argentine stem weevil attack, has been isolated. Through the development of technology and expertise, endophytes can now be successfully introduced into grasses. This technique involves the introduction of endophyte mycelium into a wound at the junction of the mesocotyl and coleoptile of ryegrass seedlings, under sterile conditions (Latch \& Christensen 1985).

Release of cultivars containing 'novel' endophyte in the next two years should allow the positive effects of endophyte to dominate the negative effects. 'Novel' endophyte has been introduced into several new ryegrass cultivars. These 'novel' endophyte/ryegrass combinations are being field tested in the summer and autumn of 1990-91, to confirm their resistance to Argentine stem weevil attack without causing ryegrass staggers in grazing lambs.

Recently a parasitoid of Argentine stem weevil, Microtonus hyperodae Loan, was introduced into quarantine in New Zealand (Goldson et al. 1990). This parasitoid has the potential for biological control of Argentine stem weevil. While it is doubtful that $\boldsymbol{M}$. hyperodae would singularly eliminate Argentine stem weevil as a problem, it is highly probable that it will provide a valuable adjunct to plant resistance, conferred by the presence of A. lolit (Goldson et al. 1990).

A. coenophialum-in-tall-fescue-has had-little effect on New Zealand grasslands agriculture to date, because all cultivars of forage tall fescues used in New Zealand do not contain A. coenophialum. This situation could change with the recent introduction of turf tall fescues, with A. coenophialum, for seed multiplication. Grazing these seed crops before closing and after harvest and feeding of crop residues has the potential to induce toxic responses.

These effects will depend on the level of $\boldsymbol{A}$. coenophialum in the crop and the ambient conditions when the straw or forage is fed and the duration and intensity of grazing. Feeding these türf fescues or their crop residues should be approached with caution, especially where the endophyte level is unknown.

The storage conditions for maintenance of viable endophyte in seed are now quite clear. Such conditions, however, are not readily available to seed merchants for storage of large quantities of seed. With the recent popularity of high endophyte ryegrass cultivars and the introduction of 'novel' endophyte, the demands for specialised seed storage will increase.

\section{REFERENCES}

Aasen, A.J.; Culvenor, C.C.J.; Finnie, E.P.; Kellock, A.W.; Smith, L.W. 1969. Alkaloids as a possible cause of ryegrass staggers in grazing livestock. Australian journal of agricultural research 20: 71-86.

Arechavaleta, M.; Bacon, C.W.; Hoveland, C.S.; Radcliffe, D.E. 1989. Effect of the tall fescue endophyte on plant response to environmental stress. Agronomy journal 81: 83-90.

Bacon, C.W.; Lyons, P.C.; Porter, J.K.; Robbins, J.D. 1986. Ergot toxicity from endophyte-infected grasses: A review. Agronomy journal 78: 106-1 16.

Bacon, C.W.; Porter, J.K.; Robbins, J.D.; Luttrell, E.S. 1977. Epichloe typhina from toxic tall fescue grasses. Applied and environmental microbiology 34: 576-581.

Belesky, D.P.; Fisherman, M.L.; Wilkinson, S.R. 1984. Effect of nitrogen fertilization and mild water stress on the distribution of nitrogen in tall fescue. Plant and soil 77: 295-303.

Belgrave, B.R.; Watt, P.C.; Brock, J.L.; Wewala, S.; Sedcole, J.R. 1990. A surveyof farmer knowledge and use of pasture cultivars in New Zealand. NZ journal of agricultural research 33: 199-211.

Bush, L.P.; Cornelius, P.C.; Buckner, R.C.; Varney, D.R.; Chapmen, R.A.; Burrus, P.B.; II, Kennedy, C.W.; Jones, T.A.; Saunders, M.J. 1982. Association of N-acetyle loline and $\boldsymbol{N}$-formyl loline with Epichloe typhina in tall fescue. Crop Science 22: 941-943.

Cunningham, I.J. 1948. Tall fescue grass is poison for cattle. NZ journal of agriculture 77: 519.

di Menna, M.W.; Mantel, P.G.; Mortimer, P.H. 1976 Experimental production of a staggers syndrome in ruminants by a tremorgenic Penicillium in soil, NZ veterinary journal 24: $45-46$.

Everest, P.F. 1983. Ryegrass staggers: An overview of the North Canterbury situation and possible costs to the farmer. Proceedings of the NZ Grassland Association 44: 228-229.

Fletcher, L.R. 1982. Observations of ryegrass staggers in weaned lambs-grazing-different-ryegrass pastures. $\bar{N} \bar{Z}$ journal of experimental agriculture IO: 203-207.

Fletcher, L.R. 1983. Effects of presence of Lolium endophyte on growth rates of weaned lambs, growing on to hoggets, on various ryegrasses. Proceedings of the NZ Grassland Association 44: 237-239.

Fletcher, L.R. 1985. Lolium endophyte and sheep performance on perennial ryegrass cultivars Proceedings of the NZ Grassland Association 47: 99-105.

Fletcher, L.R.; Barrell, G.K. 1984. Reduced liveweight gains and serum prolactin levels in hoggets grazing ryegrasses containing Lolium endophyte. NZ veterinary journal 32: 139-140.

Fletcher, L.R. and Harvey, I.C. 1981. An association of a Lolium endophyte with ryegrass staggers. NZ veterinary journal 29: 185-186.

Fletcher, L.R.; Piper, E.L. 1990. Factors besides Acremonium lolii which influence ryegrass staggers in grazing stock. Proceedings of the Ist International Symposium on Acremonium Grass Interactions fin press).

Gallagher, R.T.; Hawkes, A.D. 1986. Potential tremorgenic neurotoxins lolitrem B and aflatrem: a comparison of the tremor response in mice. Experientia 42: 823-825. 
Gallagher, R.T.; Hawkes, A.G.; Steyn, P.S.; Vleggaar, R. 1984. Tremorgenic neurotoxins from perennial ryegrass causing ryegrass staggers disorder of livestock: structure and elucidation of lolitrem B. Journal of the Chemical Sacioety, chemical communications (London): 614-616.

Gallagher, R.T.; White, E.P.; Mortimer, P.H. 1981. Ryegrass staggers: Isolation of potent neurotoxins lolitrem A and lolitrem B from staggers producing pastures. NZ veterinary journal 29: 189-190.

Garner, G.B.; Cornell, C.N. 1978. Fescue foot in cattle. pp. 45-62. In Mycotoxic fungi, mycotoxins, mycotoxicoses. Wyllie, Morehouse, Dekker (eds.) New York, NY.

Garrett, L.W.; Heiman, E.D.; Pfander, W.H.; Wilson, L.L. 1980. Reproductive problems of pregnant mares grazing fescue pastures. Journal of animal science 51: 237.

Gilruth, J.A. 1906. Meningo-encephalitis (stomach staggers) of horses, cattle and sheep. Annual Repoit of the New Zealand Department of Agriculture 14: 293-297.

Goldson, S.L. 1979b. Hyperodes bonariensis, biology and grass resistance (Coleoptera: Curculionidae). In: Crosby, T.K.; Pottinger, R.P. eds. Proceedings of the second Australasian conference on grassland invertebrate ecology. Wellington, Government Printer. p 262-264

Goldson, S.L.; McNeill, M.R.; Stufkens, M.W.; Proffitt, J.R.; Pottinger, R.P.; Farrell, J.A. 1990. Importation and quarantine of Microctonus hyperodae, South American parasitoid of Argentine stem weevil. Proceedings of the 43rd NZ Weed and Pest Control Conference: $334-338$.

Goldson, S.L.; Trought, T.E.T. 1980. The effect of Argentine stem weevil on pasture composition in Canterbury. Proceedings of the 33rd NZ Weed and Pest Control Conference: 46-48.

Hare, M.D.; Rolston, M.P.; Christensen, M.J.; Moore, K.K. 1990. Viability of Lolium endophyte fungus in seed and germination of Lolium perenne seed during five years of storage. Proceedings of the 1st International Symposium on Acremonium/Grass Interactions (in press).

Harris, W.; Hoglund, J.H. 1977. Influences of seasonal growth periodicity and $\mathrm{N}$-fixation on competitive combining abilities of grasses and legumes. Proceedings of the XIII International Grassland Congress: 239-243.

Harvey, I.C.; Fletcher, L.R.; Emms, L.M. 1982. Effects of several fungicides on the Lolium endophyte in ryegrass plants, seeds, and in culture. NZ journal of agricultural research 25: 601-606.

Hemken, R.W.; Jackson, J.A. Jr.; Boling, J.A. 1984. Toxic factors in tall fescue. Journal of animal science 58: 1011-1016.

Hoveland, C.S.; Schmidt, S.P.; King, C.C. Jr; Odum, J.W.; Clark, E.W.; McGuire, L.W.; Smith, L.A.; Grimes, H.W.; Holliman, J.L. 1983. Steer performance and association of Acremonium coenophialum fungal endophyte on tall fescue pasture. Agronomy journal 75: 821-824.

Johnson, M.C.; Dahlman, D.L.; Siegel, M.R.; Bush, L.P. Latch, G.C.M.; Potter, D.A.; Varney, D.R. $198 \%$ Insect feeding deterrents in endophyte-infected tall fescue. Applied environmental microbiology 49: 568-571.
Johnson, M.C.; Pirone, T.P.; Siegel, M.R.; Varney, D.R 1982. Detection of Epichloe typhina in tall fescue by means of enzyme-linked immunosorbent assay. Phytopathology 72: 647-650.

Kain, W.M.; Wyeth, T.K. 1982. Argentine stem weevil (Hyperodes bonariensis Kuschel) resistance in perennial and hybrid ryegrasses. NZ journal of agricultural research 25: 255-259.

Kearns, M.P. 1985. Tall fescue toxicity: An investigation of idiopathic bovine hyperthermia (IBH) in North Auckland peninsula. Proceedings of the NZ Grassland Association 47: 183-186.

Kelsey, J.M. 1958. Damage in ryegrass by Hyperodes griseus Hust. NZ journal of agricultural research $I$ : 790-795.

Keogh, R.G. 1973. Induction and prevention of ryegrass staggers in grazing sheep. $N Z$ journal of experimental agriculture l: $55-57$.

Keogh, R.G. 1978. Development and control of rveerass staggers in sheep. Proceedings of the NZ Society of Animal Production 38: 47-52.

Keogh, R.G. 1983. Ryegrass staggers: Management and control. Proceedings of the NZ Grassland Association 44: $248-250$.

Latch, G.C.M. 1982. Incidence of endophytes in seed lines and their control with fungicides. Proceedings of the NZ G rassland Association 44: 251-253.

Latch, G.C.M.; Christensen, M.J. 1982. Ryegrass endophyte, incidence and control. NZ journal of agricultural research $25 \cdot 443-448$,

Latch, G.C.M.; Christensen, M.J. 1985. Artifical infection of grasses with endophytes. Annals of applied biology 107: $17-24$.

Latch, G.C.M.; Christensen, M.J.; Samuels, G.J. 1984. Five endophytes of Lolium and Festuca in New Zealand. Mycotaxonomy 20: $535-550$.

Latch, G.C.M.; Falloon, R.E.; Christensen, M.J. 1976. Fungi and ryegrass staggers. $N Z$ journal of agricultural research 19: 233-242.

Latch, G.C.M.; Hunt, W.F.; Musgrave, D.R. 1985. Endophytic fungi affect growth of perennial ryegrass. NZ journal of agricultural research 28: 165-168.

Lipham, L.B.; Thompson, F.N.; Stuedemann, J.A.; Sartin, J.L. 1988. Effects of metoclopramide on steer grazing endophyte-infected fescue. Journal of animal science 66 (Suppl. 1): 373.

Lloyd, A.B. 1959. The endophytic fungus of perennial ryegrass. NZ journal of agricultural research 2: $1187-1194$

Loan, C.C.; Lloyd, D.C. 1974. Description and field biology of Microctonus hyperodae Loan (Hymenoptera: Braconidae, Euphorinae) a parasite of Hyperodes bonariensis in South America (Coleoptera: Curculionidae). Entomorphaga 19: 7.12.

Lyons, P.C.; Plattner, R.D.; Bacon, C.W. 1986. Occurrence of peptide and clavine ergot alkaloids in tall fescue grass. Science 232: 487-489.

Lyons, P.C.; Evans, J.J.; Bacon, C. 1990. Effects of the Fungal Endophyte Acremonium coenophialum on Nitrogen Accumulation. and Metabolism in Tall Fescue. Plant physiology 92: 726-732.

McLennan, E. 1920. The endophytic fungus of Lolium, 1. Proceedings of the R oyal Society of Victoria (N.S.) 32: 252-301.

Mortimer , P.H. 1983. Ryegrass stagger: Clinical, Pathological and Aeteological aspects. Procedings of the NZ Grassland Association 44: 230-233. 
Mortimer, P.H.; Fletcher, L.R.; di Menna, M.E.; Harvey, I.C.; Smith, G.S.; Barker, G.M.; Gallagher, R.T.; White, E.P. 1982. Recent advances in ryegrass staggers. Proceedings of the Ruakura farmers' conference 34: 71-74.

Mueller, J.P. 1985. An overview of the tall fescue endophyte problem in U.S.A. Proceedings of the $N Z$ Grassland Association 47: 183-186.

Musgrave, D.R. 1984. Detection of an endophytic fungus of Lolium perenne using enzyme-linked immunosorbent assay (ELISA). NZ journal of agricultural research 27: 283-288.

Musgrave, D.R.; Fletcher, L.R. 1984. The development and application of ELISA detection of Lolium endophyte in ryegrass staggers research. Proceedings of the NZ Society of Animal Production 44: 185-187.

Neill, J.C. 1940. The endophyte of ryegrass (Lolium perenne). New Zealand journal of science and technology A21: 280-291.

Neill, J.C. 1941. The endophytes of Lolium and Festuca. $N Z$ journal of science and technology A23: 185-1 93.

Philipson, M.N.; Christey, M.C. 1986. The relationship of host and endophyte during flowering, seed formation, and germination of Lolium perenne. NZ journal of botany 24: 125-134.

Piper, E.L. 1989. Liver function and ryegrass staggers. NZ veterinary journal 37(4): 173-1 74 .

Piper, E.L.; Fletcher, L.R. 1990. Influence of a dopamine antagonist on ryegrass staggers. Proceedings of the Ist International Symposium on Acremonium/Grass Interactions (in press).

Prestidge, R.A. and Gallagher, R.T. 1985. Lolitrem B - a stem weevil toxin isolated from Acremonium infected ryegrass. Proceedings of the 38th NZ Weed and Pest Control Conference: $38-40$.

Prestidge, R.A.; Pottinger, R.P.; Barker, G.M. 1982. An association of Lolium endophyte with ryegrass resistance to Argentine stem weevil. Proceedings of the 35th NZ Weed and Pest Control Conference: 119-122.

Prestidge, R.A.; Pottinger, R.P.; Barker, G.M. 1985. Argentine stem weevil biology, damage, and control, summary. Aglink FPP48. Information services, MAF, Private Bag, Wellington, -NZ-3p.

Rolston, M.P.; Hare, M.D.; More, K.K.; Christensen, M.J. 1986. Viability of Lolium endophyte fungus in seed stored at different moisture contents and temperatures. NZ journal of experimental agriculture 14: $297-300$

Rowan, D.D.; Gaynor, D.L. 1986. Isolation of feeding deterents against Argentine stem weevil from ryegrass infected with Acremonium lolii. Journal of chemical ecology 12: 647-658.

Rumsey, T.S.; Steudeman, J.A.; Wilkinson, S.R.; Williams. D.J. 1979. Chemical composition of necrotic fat lesions in beef cows grazing fertilised "Kentucky-31" tall fescue. Journal of animal science 48: 673 .

Sampson, K. 1933. The systemic infection of grasses by Epichtoe typhina (Pers.) tul. Transactions of the British Mycological Society 18: 30-47.

Sampson, K. 1935. The presence and absence of an endophytic fungus in Lolium temulentum and $L$. perenne. Transactions of the British Mycological Society 19; $337-343$
Sampson, K. 1937: Further observations on the systemic infection of Lolium. Transactions of the British Mycological Society 21: 84-97.

Siegel, M.R.; Johnson, M.C.; Varney, D.R.; Nesmith, W.C.; Buckner, R.C.; Bush. L.P.; Burrus. P.B.: Jones, T.A.; Boling, J.A. 1984. A fungal endophyte in tall fescue: Incidence and dissemination. Phytopathology 74: 932-937.

Siegel, M.R.; Latch, G.C.M.; Johnson, M.C. 1985. Acremonium fungal endophytes of tall fescue and perennial ryegrass: Significance and control. Plant disease 69: 179-183.

Snell, W.H.; Dick, D.A. 1971. A Glossary of Mycology. Cambridge. Mass.: Harvard University Press.

Stevens, D.R.; Hickey, M.S. 1990. Effects of endophytic ryegrass on the production of ryegrass/white clover pastures. Proceedings of the Ist International Symposium on Acremonium/Grass Interactions (in press).

Suckling, F.E.T. 1965. Hill Pasture Improvement. Newton King Group and DSIR, Wanganui.

Suckling, F.E.T. 1975. Pasture management trials on unploughable hill country at Te Awa. III. NZ journal of experimental agriculture 3: 351-436.

Sutherland, B.L.; Hoglund, J.H. 1989. Effect of ryegrass containing the endophyte Acremonium lolii on the performance of associated white clover and subsequent crops. Proceedings of the NZ Grassland Association S0: $265-269$

Thornton, R.H. 1964. An examination of ergot in relation to ryegrass staggers. NZ veterinary journal 12: 13-16.

Vogl, A.E. 1898. Mehl und die anderen Mehlprodukte der Cerealien und Leguminosen Nahrungsm. Unters Hyg. Warenk. 12: 25-29.

Walker, J.C. 1950. Plant Pathology. New York: McGrawHill.

Wallner, B.M.; Booth, N.H.; Robbins, J.D.; Bacon, C.W.; Porter, J.K.; Kaiser, T.E.; Wilson, R. and Johnson, B. 1983. Effect of endophytic fungus isolated from toxic pasture grass on serum prolactin concentrations in the lactating cow. American journal of veterinary research 44: 1317-1322.

Weedon, C.M.; Mantle, P.G. 1987. Paxilline biosynthesis by Acremonrum- Ioliae; "a- step-towards defining the origin of lolitrem neurotoxins. Phytochemistry 26: 969-97 1.

Welty, R.E.; Azevedo, M.D.; Cook, K.L. 1986. Detecting viable Acremonium endophytes in leaf sheaths and meristems of tall fescue and perennial ryegrass. Plant disease 70: 431-435.

Welty, R.E.; Milbrath, G.M.; Faulkenberry, D.; Azevedo, M.D.; Meek, L.; Hall, K. 1986. Endophyte detection in tall fescue seed by staining and ELISA. Seed science and technology 14: 105-116.

Yates, S.G.; Plattner, R.D.; Garner, G.B. 1985. Detection of ergopeptide alkaloids in endophyte infected toxic Ky-31 tall fescue by mass spectrometry/mass spectrometry. Journal of agricultural and food chemistry 33: 7 19-722. 